\title{
Cold Contaminant-free Iobenguane I-131
}

National Cancer Institute

\section{Source}

National Cancer Institute. Cold Contaminant-free lobenguane I-131. NCI Thesaurus.

Code C82344.

An I 131 radioiodinated synthetic analogue of the neurotransmitter norepinephrine, manufactured with a proprietary process, with radioisotopic and potential antineoplastic activities. Cold contaminant-free iobenguane I 131 (MIBG) localizes to adrenergic tissue and may be used to image or eradicate tumor cells that accumulate and metabolize norepinephrine. This agent is manufactured using a technology that avoids the production of unwanted "cold contaminants" (i.e., carrier molecules), which may cause undesirable side effects and compete with MIBG for binding on targ et receptor sites. 